\title{
Method of Drawing Up a Road Map that Considers the Synergy Effect for IT Investment
}

\author{
Tadasuke Nakagawa Member (Hitachi, Ltd) \\ Shigeyuki Tani Member (Hitachi, Ltd) \\ Masaharu Akatsu Member (Hitachi, Ltd) \\ Norihisa Komoda Member (Osaka University)
}

Keywords : IT investment, determining priority, decision-making, business challenge, synergy effect, risk

Managers must account for all the investments made in a competitive business environment that changes rapidly, and it is becoming increasingly important that they carefully evaluate IT investments before making them. Moreover, while managers can evaluate the probable impacts of individual IT projects, they find it difficult to predict the overall effect of two or more of them.

Most IT projects exceed their budgets and do not perform as well as expected. And after considering the risks of development delay and budget overruns, managers need to think about assigning an IT project a priority level that maximizes its effect while keeping its cost within the budget. Because the IT measure must be considered in light of the prevailing business challenges, all the while taking account of various constraint condition and risks, there is a pressing need to develop a method for determining the priority of an IT investment.

A schedule chart showing the order of introducing each measure (called a "road map") will help managers make decisions about investing in two or more IT measures. Here, a greater effect might be obtained by introducing two or more measures at the same time. On the other hand, the effect of two measures might not be significant even if they are introduced at the same time. That is, there is a synergy effect when two or more measures are introduced. What's more, while some measures need to be introduced and others do not, there has been no method for drawing up a road map that takes these various factors into account.

The way in which the road map is drawn up is based on the business challenge level and the constraint conditions are set. The solution is calculated in such a way that maximizes the evaluation value of the road map as a whole. We have the following two kinds of frames:

(1) Two-axis frames with time and budget axes.

(2) Two-axis frames with time and staff axes.

When drawing up the road map, we need to build the constraint condition of the entire road map into each these two kinds of frames for each measure.

It is impossible to calculate the evaluation value of the whole road map all cases because the computational complexity is expected to be $O(n !)$ when the number of measures is $n$. We therefore propose a method for drawing up the road map by dividing its calculation into two steps, one calculating the initial solution and the other calculating an optimization solution.

Firstly, to maximize the overall effect of the road map, the initial solution of the road map is calculated as one in which measures are introduced sequentially in descending order of business challenge level. Next, the road map is corrected to consider the synergy effect. An example of this correction procedure is shown in Fig. 1. When the synergy effect is considered, those measures are actually replaced if the business challenge level of the entire road map is high before the measure is replaced.

We applied the proposed method to the fictitious constraint condition data simpler that actual problem data. When the synergy effect is considered, a road map that is actually suitable can be drawn up. In addition, the business challenge level of road map that considered the synergy effect is bigger than that of not considered it. Road map users can reach consensus because they can logically explain the order of introducing measures by considering the constraint conditions without neglecting the investment decision-making process.

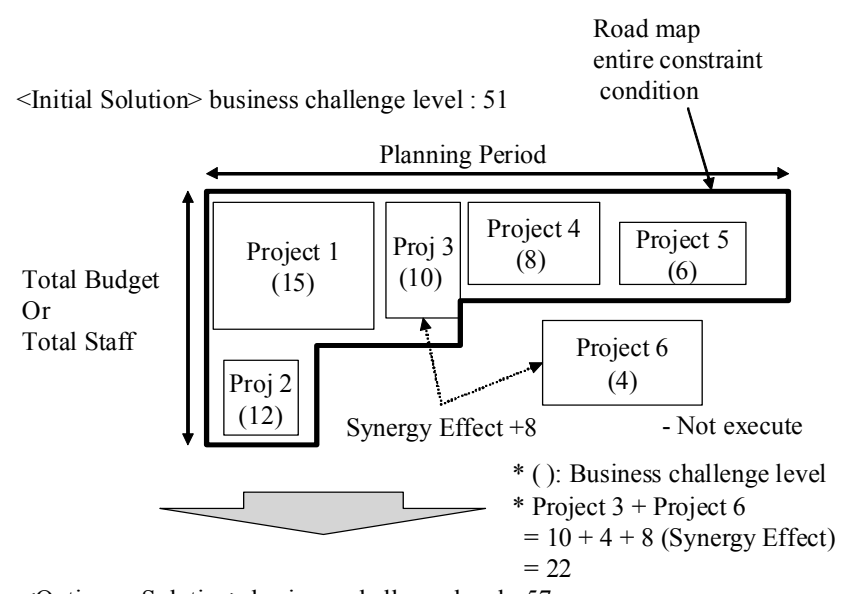

$<$ Optimum Solution $>$ business challenge level : 57

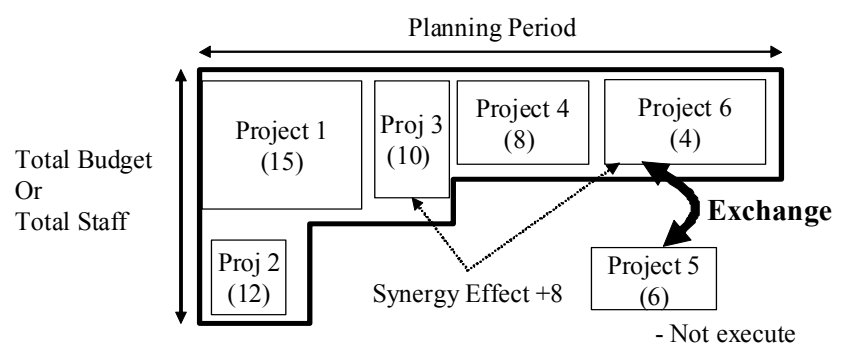

Fig. 1. Correction of road map that considers synergy effect 


\title{
IT投資戦略立案のための相乗効果を考慮した ロードマップ構築手法
}

\author{
正員 中川 忠輔* 正員 谷 繁幸* \\ 正員 赤津 雅晴* 正 員 薦田 憲久**
}

\author{
Method of Drawing Up a Road Map that Considers the Synergy Effect for IT \\ Investment
}

Tadasuke Nakagawa*, Member, Shigeyuki Tani*, Member, Masaharu Akatsu*, Member, Norihisa Komoda**, Member

\begin{abstract}
IT governance lacks a comprehensive vision of the investment in two or more projects. It is necessary to decide the priority level that maximizes the effect under the constraint conditions. The problem is complex because while sometimes a greater effect can be obtained by introducing two or more measures at the same time, other times the effect of two measures introduced at the same time might not be significant. Although there is thus a synergy effect when two or more measures are introduced, no method for drawing up an investment-decision road map considered that effect. We therefore developed one. What a decision-maker thinks about when considering the introduction of two or more measures can be visualized by drawing up a comprehensive road map that satisfies constraint conditions such as effectiveness of measure, budget, time, staff size, order of introduction, the synergy effect. Road map users can easily reach a consensus because the map, by taking into account the constraint conditions and the investment decision-making process, helps them logically explain the order in which the measures should be introduced.
\end{abstract}

キーワード：IT 投資，優先順位付け，意思決定，経営課題，相乗効果，リスク

Keywords: IT investment, determining priority, decision-making, business challenge, synergy effect, risk

\section{1. はじめに}

競争の激しい，急速に変化するビジネス環境においては， あらゆる投資に対して，光の経営者に対する説明責任が求 められるようになっている。IT 投資も同樣であり，光の投 資の妥当性を合理的に評価することの重要性はますます大 きくなっている ${ }^{(1)}(2)$ 。また，企業経営活動においては, IT を経営視点で評価するべきであるが, 個々のプロジェクト 単位では評価を行っているとしても，IT ガバナンスにお ける複数プロジェクトの投資に関しては, 総合的な視点が 欠如しているのが実情である。一方，8000 以上の IT プロ

\footnotetext{
* (株) 日立製作所 システム開発研究所

厂 244-0817 横浜市戶塚区吉田町 292 番地

Systems Development Laboratory, Hitachi, Ltd.

292, Yoshida-cho, Totsuka-ku, Yokohama 244-0817

** 大阪大学大学院 情報科学研究科

干 565-0871 吹田市山田丘 2-1

Graduate School of Information Science and Technology, Osaka University

2-1 Yamadaoka, Suita 565-0871
}

ジェクトの大半が予算を超過し, 期待した目標や品質に達 しておらず，当初予定した機能が遅延なく，予算の範囲内 で完了したプロジェクトは, わずか $16.2 \%$ であるという報 告がある ${ }^{(3)}$ 。開発遅延や予算オーバなどのリスクも考慮し た上で，限られた予算の中で効果を最大化するような優先 順位を考える必要がある。このような背景から，IT 戦略策 定の際には, 経営課題と IT 施策を関連付けると共に, 樣々 な制約・リスクを考慮した，説得力のある「IT 投資優先順 位付け」をする手法の確立が急務となっている。

複数施策の導入の際には, 施策の重要度を決定し, 制約 を考慮した上で施策の重要度の高いものを優先的に導入す ればよい。ここでは，ロードマップと呼ばれる，各施策の 導入順序を表す計画図を作成する。施策の重要度を決定す るには意思決定者の勘や感覚をいくつかの主観的評価から 最大公約数的判断を抽出し意思決定を行う AHP (Analytic Hierarchy Process) がある ${ }^{(4)}$ 。本論文ではこの重要度を， 経営に対するインパクトという意味で経営達成度と呼ぶ。 次に, 施策の導入手順を, 例えば, 時間的要素を中心として 計画する PERT (Program Evaluation and Review Tech- 
nique) を用いて ${ }^{(5)}$, 制約条件を考慮した施策の実現順位を 算出することが可能である。また, ProSight では, 重要度 や施策間の順序を設定しプロジェクトの実行時期や予算等 の管理を行うツールを開発している ${ }^{(6)}$ 。しかし , 複数の施 策を同時に実行することでより大きな効果を得る，あるい は逆に同時に実行してもあまり意味のない施策などといっ た, 施策の相乗効果が存在する。また, 複数の施策には, 必 ず実行すべきもの，あるいは後回しにしてもよいものも存 在するが，これらを考慮したロードマップの構筑方法がな かった。

本研究では, 複数施策の投資意思決定を支援するロード マップ構築手法を提案する。経営達成度と予算・時間・人 員・順序・相乗効果などの制約条件を満足し，矛盾のない， より効果の大きいと予想されるロードマップを構築するこ とで，ユーザの考える投資優先順位を具現化する。投資意 思決定のために本手法を利用する際には，複数の関係者が 集まり, 制約条件の数值をお互いに確かめ合うことで確定 させ , 谷の值を元に本手法でロードマップを構築する。ロー ドマップを各関係者が確認し，設定した制約条件の矛盾点 や誤りを発見し，修正していくことで施策の着手順序を論 理的に説明でき，意見を出し合い，納得した数值を利用す ることで , 関係者の合意を得ることが可能となる。

\section{2. 問題の定義}

IT 投資戦略立案においては必ずしも施策の効果を考えら れるわけではなく，ロードマップ構築は意思決定者の裁量 に左右されたり，施策の効果を予測する努力が惜しまれる 場合がある。これに対し，本論文ではこの効果を定量的な 数值で表して意思決定を行うべきであると考える。複数の 施策候補の中から実行する施策を決定する際には，投資意 思決定者が考える施策の定性的な効果を定量的な数值に変 換し，制約条件を考慮した上で，ある一定の期間で効果の 数值が高いものを優先的に実行する。

本研究では，表 1 に示す制約条件を設定する。制約に関 しての設定項目は，投資全体に関する全体制約，各施策の 情報である各施策制約に分類される。また，経営戦略策定 時における施策の予算や導入期間の見積もりは精度が粗く， 将来の不確実性が大きいと考えられる。以下の各設定項目 について不確実性がある場合はリスク条件を設定する。表 1 の各項目についての説明を以下に示す。また図 1 , 表 2 に 制約条件設定項目の概要を示す。図 1 に示すように，ロー ドマップは，ここで設定する制約条件に合わせた表現方法 を用いている。

(1) 全体予算

投資全体の各年度の投資予算額（¥）である。

(2) 全体人員

投資全体の各年度の予定人的リソース量 (人) である。

(3) 全体計画期間

計画の対象とする期間 (年) である。

(4) 経営達成度
各施策の経営に対する貢献度合い (効果) の大きさ を示す。例えば，図 2 に示すように経営達成度を数 值化する方法が挙げられる。ここでは，経営課題に 結びついた重要な施策を優先的に実行するべきであ ると考え, 経営課題の重要性の度合いと, 光の経営

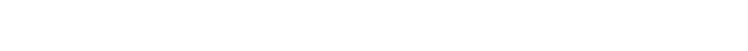
かを数值で表し，各々を乗じることで各施策がどの 程度経営に影響を与えるかを数値化する。施策 $i$ の 経営達成度 $B_{i}$ は, 経営課題 $j$ の重みパラメータ $w_{1 j}$ と, 施策 $i$ が経営課題 $j$ に与える影響度合い $w_{2 i j}$ を 用いて下記のように表される。

$$
B_{i}=\sum_{j} w_{1 j} w_{2 i j} \div 100 \ldots \ldots \ldots \ldots \ldots
$$

図 2 において，A が重みパラメータ $w_{1 j}, \mathrm{~B}$ が影響 度合い $w_{2 i j}, \mathrm{C}$ か経営課題達成度 $B_{i}$ を表している。

(5) 導入時間

各施策の導入にかかる期間 (月) である。

(6) 可能時期

ある施策は何ヶ月後以降でないと実行できないとい う制約が存在する。各施策が開発可能な時期の範囲 (月）を設定する。

（７）実行必要性

各施策を全体計画期間内に必ず実行する必要がある か否かを示す。この必要性がない施策は, ロードマッ プ構築過程において全体計画期間内に実行できなけ れば，光れ以降に実行される。

(8) 導入順序

一方の施策を導入しないと他方か導入できない場合 に設定する。

(9) 排他的施策

複数施策のうち 1 施策のみ可能な場合に設定する。

(10) 相乗効果

施策には，複数の施策を同時に実行することでより 大きな効果を得る，あるいは逆に同時に実行しても 意味のない施策などの, 施策の相乗効果が存在する。 複数の施策を行うことによって相互に関係する施策が 得る効果であり, 経営達成度の変化の大きさで表す。

（11）施策予算

各施策に必要な額（¥）である。

(12) 施策人員

各施策に必要な専任人員数 (人) である。

また，以下のリスク条件が存在する。

(1) 導入時間のリスク

導入時間が (5) 導入時間の見積りとずれる幅 (月) である。

(2) 施策予算のリスク

施策予算が (11) 施策予算の見積りとずれる幅 ( $¥$ ) である。

(3) 施策人員のリスク

施策人員が $(12)$ 施策人員の見積りとずれる幅 (人) 
表 1 制約条件設定項目

Table 1. Constraint conditions.

\begin{tabular}{|c|c|c|c|}
\hline No. & Category1 & Category2 & Item \\
\hline (1) & \multirow{3}{*}{$\begin{array}{l}\text { for the } \\
\text { total } \\
\text { investment }\end{array}$} & \multirow{2}{*}{ Resource } & Total budget \\
\hline (2) & & & Total staff \\
\hline (3) & & Time & Planning period \\
\hline$(4)$ & \multirow{9}{*}{$\begin{array}{l}\text { for } \\
\text { each } \\
\text { measure }\end{array}$} & Effect & Business challenge level \\
\hline (5) & & \multirow[t]{3}{*}{ Time } & Introduction period \\
\hline (6) & & & $\begin{array}{l}\text { Time that measure } \\
\text { can be introduced }\end{array}$ \\
\hline (7) & & & Introduction necessity \\
\hline (8) & & \multirow[t]{3}{*}{ Relation } & Introduction order \\
\hline (9) & & & Exclusive measure \\
\hline$(10)$ & & & Synergy effect \\
\hline (11) & & \multirow[t]{2}{*}{ Resource } & Introduction budget \\
\hline (12) & & & Introduction staff \\
\hline
\end{tabular}

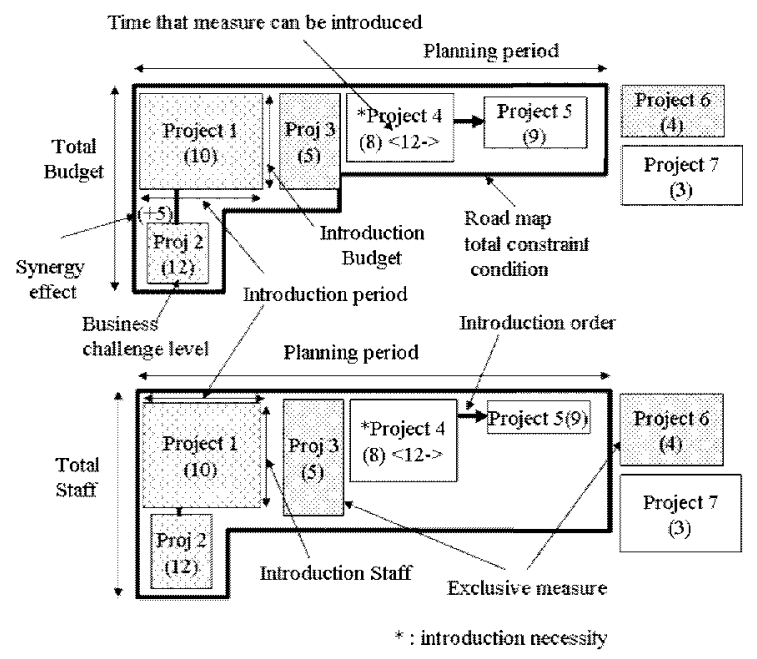

図 1 ロードマップの表現例

Fig. 1. Example of road map (1).

\section{表 2 施策間制約の設定例}

Table 2. Example of relation constraint conditions.

\begin{tabular}{|l|c|c|c|c|}
\hline & Project1 & Project2 & Project3 & Project4 \\
\hline Project1 & & $1 \times 2$ & & \\
\hline Project2 & $1 \times 2$ & & $2 \rightarrow 3$ & \\
\hline Project3 & & $2 \rightarrow 3$ & & +5 \\
\hline Project4 & & & +5 & \\
\hline
\end{tabular}

$\rightarrow$ : Introduction order constraint condition

$x$ : Exclusive measure constratint condition

$+:$ Up impact

-: Down impact

である。

なお，図 1 では，横軸を時間，縦軸を予算として，各施 策および全体の制約条件の大きさを表し，横軸の各々の時 点でどれほどの予算が消費されるかを示してる。また同樣 に横軸を時間, 縦軸を人員として, 各々の時点でどれほど の人員が消費されるかを示してる。また表 1 では, 施策間 制約を示しており，縦軸の施策と横軸の施策の交点に，光 の内容を示す。導入順序がある場合は「 $\longrightarrow\lrcorner$, 排他的施策は $\ulcorner\times 」$, 相乗効果がある場合は正また負の数値で示す。

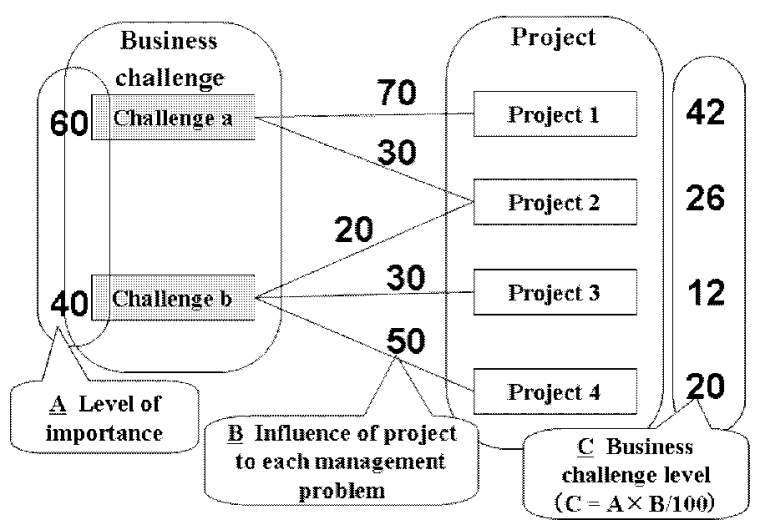

図 2 経営達成度の算出例

Fig. 2. Example of calculating.

本研究では, 以上のような制約内に各施策を収め, ロー ドマップ中にある施策の累積の経営達成度がある一定の期 間内に最大となるような施策のロードマップの構築方法を 取り扱う。なお, 施策の数は数十から数百, 各期の全体予 算は数千万円から数億円, 全体人員は数十人程度, 全体計 画期間は 3 から 5 年, 同時に実行される施策数は数十個程 度を想定している。なお, ロードマップに沿って施策を実 行している途中に割り込みがあった場合は, (a) 弚の時点 で以降のロードマップを作り直す, (b) 谷の施策の予算・人 員を別途確保する，などの方法を取る。

\section{3. ロードマップ構築手法}

〈3. 1 \ロードマップ構築の流れ 企業が複数施策への 投資を実施する前に行う投資優先順位付けに関して，より 効果の大きいと予想されるロードマップを構築する。ロー ドマップ構築法として , 下記に示す手順に従った手法を提 案する。

（1）経営達成度および制約条件の設定

複数の施策光れ光れの重要性を示す経営達成度や， 樣々な制約条件を設定する。

(2) ロードマップ構築

(1) で設定された条件を考慮したロードマップを構 筑する。

(3) ロードマップ提示

構築されたロードマップを意思決定者に提示する。 ロードマップが意思決定者の意思に沿わない，ある いは (1) で設定された条件に矛盾や不備などがあつ た場合は (1)に移り条件を設定し直す。

ロードマップを繰り返し修正することで , 関係者の合意 を形成することが可能である。

〈3. 2〉相乗効果を考慮したロードマップ構築 2 章で 設定した制約条件をもとにロードマップを構築する。具体 的には，図 1 のロードマップ全体制約枠 (時間, 予算・人 員の制限) の中で, 経営達成度の大きい施策から，導入順 序や相乗効果などを満足するよう各施策の枠を埋め込んで いき, 全体としてロードマップの評価值が高くなるような 
解を算出する。つまりロードマップ中に存在する施策の経 営達成度の合計値 (累積経営達成度) を最大化する。ここ では, 経営達成度が大きい施策ほど企業経営に貢献すると 考え, 先に実行する。また，例えば，ジョブショップスケ ジューリング問題のように, 通常全ての作業が完了するま での総作業時間を最小にすることを目的とするアルゴリズ ムが存在するが，一般に計算時間が長く ${ }^{(7)}$, ロードマップ を意思決定者に提示し, 制約条件を繰り返し設定し直すこ とを考えても高速にロードマップを構筑することか望まれ る。また，ロードマップを構築する際に，経営者のような 意思決定者は必ずしも複雑なアルゴリズムを理解できると は限らず，明快な方法が好まれると考え，単純な構築方法 を採用している。

各施策を図 1 のような 2 軸で構成される枠と捉えたとき， 以下の二種類の枠が考えられる。

（1）時間と予算の 2 軸による枠

(2) 時間と人員の 2 軸による枠

ロードマップ構築の際には, 各施策が $(1),(2)$ の両方の観 点からロードマップ全体制約枠内に収まる必要がある。

なお， $n$ 個の施策の順序は $n !$ 通りとなり，計算量が膨大 となることが予想されるため, 全通りの計算を行うのは不 可能である。光こで, ロードマップの初期案を求め, 弚の 後最適化計算を行うことによりロードマップを構築する方 法を提案する。以下に关の手順を示す。

(1) 施策 $i$ の経営達成度 $I_{i}$ の大きい順に施策リス卜 $L=\left\{l_{1}, l_{2}, \ldots, l_{n}\right\}$ (施策数: $\left.n\right)$ を作成する。

（2）順序制約が存在するため，経営達成度の順に並へ 替えた後に順序制約を満足するように施策リスト $L$ の組み替えを行う。施策リスト $L$ 中のある施策 $l_{A}$ より施策 $l_{B}$ が後方に位置するが, 施策 $l_{A}$ より施策 $l_{B}$ を先に実行すべき場合，施策 $l_{B}$ を施策 $l_{A}$ の前に 挿入する。

（3）実行必要性が必須と設定されている施策 $i$, 全 体制約（全体計画期間 $T A$, 全体予算 $B A_{j}$ ，全体人 員 $M A_{j}$ ，時期 $\left.j=\{1,2, \ldots, T A\}\right)$ および，施策 $i$ の可能時期を満足する時期 $t\left(T_{i a}<t<T_{i b}\right)$ のj ち，経営達成度 $I_{i}$ の大きい施策を先に実行するため に，最も遅い時期を光の施策 $i$ の実行時期 $T_{i}$ と仮決 めし，該当期間の全体制約の予算 $B A_{j}$ と人員 $M A_{j}$ を，施策予算 $B_{i}$ および施策人員 $M_{i}$ だけ減らす。つ まり, $B A_{T i}=B A_{T i}-B_{i}, M A_{T i}=M A_{T i}-M_{i}$ である。

(4) 施策リスト $L$ の順に施策 $i$ の実行時期 $T_{i}$ を決定 する。施策 $i$ が全体制約および, 可能時期を満足す る時期 $t\left(T_{i a}<t<T_{i b}\right)$ のうち, 最も早い時期を 兴の施策の実行時期 $T_{i}$ とし，該当期間の全体制約の 予算 $B A_{j}$ と人員 $M A_{j}$ を，施策予算 $B_{i}$ および施策 人員 $M_{i}$ だけ減らす。つまり, $B A_{T i}=B A_{T i}-B_{i}$, $M A_{T i}=M A_{T i}-M_{i}$ である。実行必要性が必須と 設定されている施策の場合は，仮決めされている実
行時期 $T_{i}$ を算出し直す。なお, 制約を満足する実行 時期 $T_{i}$ が存在しない場合は炎の施策は全体計画期間 $T A$ 以降に実行する。

（5）（4）を全ての施策 $i$ に関して繰り返すことで各施 策の実行時期 $T_{i}$ を決定することが可能である。但 し，ある施策の実行時期を決定したとき，光の排他 的施策は実行しないものとする。

以上がロードマップの初期案であり, 以降, 相乗効果を考慮 するためロードマップを修正する。図 3 に修正の例を示す。

（1）正の相乗効果があり，かつロードマップ中にない 施策 $i$ のう経営達成度 $I_{i}$ の大きい施策を一つ選択 する。

（2）選択した施策 $i$ を挿入する分, 累積経営達成度 $S I$ が出来るだけ小さくならないように, ロードマップ 中の施策のうち経営達成度 $I_{i}$ の小さい施策 $i$ から順 に全体制約を満足するまで抜き出す。なお，累積経 営達成度 $S I$ はロードマップ中に存在する施策 $i$ の 経営達成度 $I_{i}$ の合計値に相乗効果の大きさ $S_{i k}(i, k$ : 施策) を加算したものである。

（３）相乗効果を考慮した上でロードマップ全体の累積 経営達成度 $S I$ が入れ替える前に比べて大きくなる 場合は，光れらの施策を実際に入れ替える。

（4）（1）から (3) の操作を，正の相乗効果がありロー ドマップ中にない施策全てに関して行う。

（５）ロードマップ中に負の相乗効果がある施策同士が ある場合は，一方の施策をロードマップ中から除外 する。

（6）除外した施策の代わりにロードマップ中にない施 策 $i$ のち，累積経営達成度 $S I$ が出来るだけ大き くなるように, 経営達成度 $I_{i}$ の大きい施策から順に 挿入する。

（７）相乗効果を考慮した上でロードマップ全体の累積 経営達成度 $S I$ が入れ替える前に比べて大きくなる 場合は，光れらの施策を実際に入れ替える。

（８）（6）と（7）の操作を施策を插入できなくなるま で繰り返す。

（9）（5）から（8）の操作をロードマップ中の施策全 てに関して行う。

以上の手順により，相乗効果を考慮したロードマップを 構築することが可能である。なお，全体予算や全体人員， 全体計画期間に対して施策予算や施策人員, 導入時間が小 さい場合は提案手法が有効であるが, 全体の制約条件に対 して各施策の制約条件の值が大きい場合には光の施策は実 行できず場合によっては何の施策も実行しない空のロード マップが得られる可能性がある。これは制約条件の設定が 不適切であることを示しており, 制約条件の再設定が望ま れる。

〈3· 3〉リスクを考慮したロードマップ構築 表 1 の リソース制約，時間制約については将来について不確実性 (リスク) を考慮する必要がある。例えば, 施策の開発に遅 


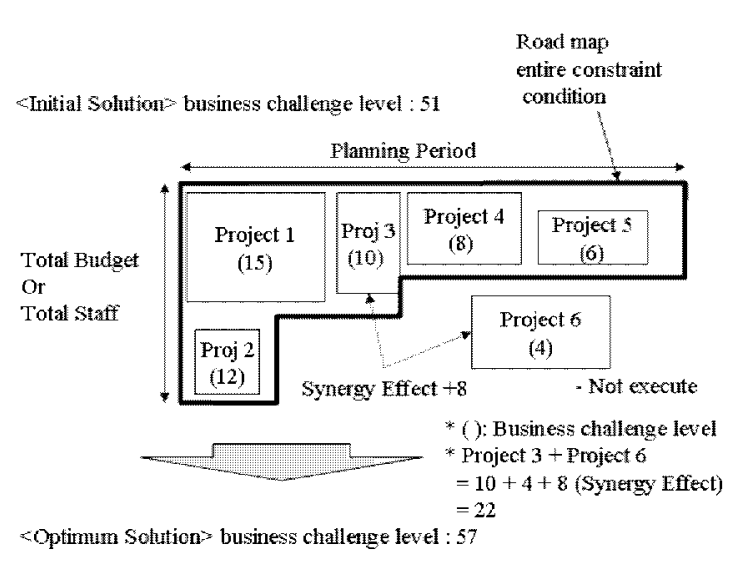

Planning Period

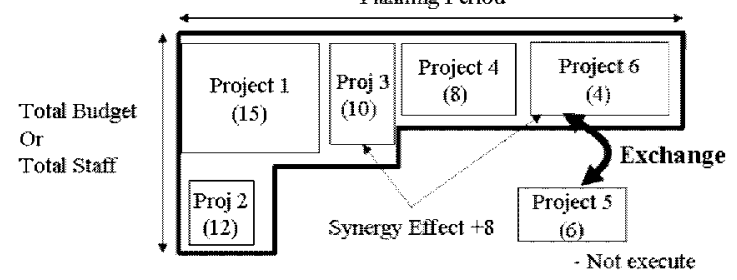

図 3 相乗効果を考慮したロードマップの修正

Fig. 3. Correction of road map that considers synergy effect.

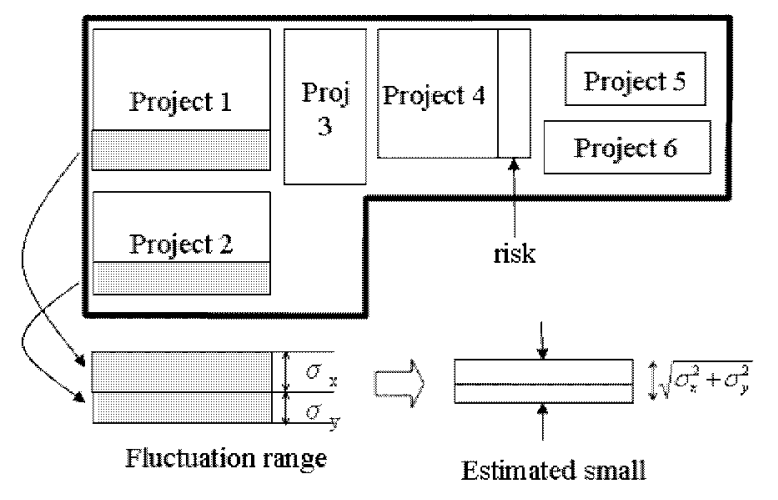

図 4 余裕幅の考え方

Fig. 4. Idea of width of margin.

れが出る場合や, 施策の導入のための予算オーバなどが考 えられる。こういったリスクに対応するため，不確実性の 存在する項目については, 期待值と変動幅を設定する。例 え施策の開発に遅れが出ても全体の計画に影響を与えない ことが望ましいため, 各施策の不確実性の大きさに合わせ て余裕のあるロードマップを構築する。つまり, 期待値と 変動幅を足し合わせた值を改めて兴の制約条件の值と設定 してロードマップを算出する。但し，図 4 に示すように複 数の施策を同時に実行する場合は, リスク分散の考え方か ら変動の幅を小さく見積もることが可能である。施策 1 と 施策 2 を同時に実行する場合, 施策 1 の変動幅 $\sigma_{x}$, 施策 2 の変動幅 $\sigma_{y}$ とすると, 例えば変動幅を標準偏差と捉えて, 施策の各值の変動が正規分布すると仮定する。分散の和の 定義より，以下の式が成り立つ。

$$
\sigma_{x+y}=\sqrt{\sigma_{x}^{2}+2 \sigma_{x y}+\sigma_{y}^{2}}
$$

\section{表 3 利用データ (全体制約)}

Table 3. Use data (for the total investment).

\begin{tabular}{|l|l|l|l|l|l|l|l|}
\hline No. & Item - Period & 1 & 2 & 3 & 4 & 5 & 6 \\
\hline (a) & Total budget $(\mathrm{M} ¥)$ & 40 & 80 & 80 & 100 & 50 & 50 \\
\hline (b) & Total staff (man) & 10 & 10 & 12 & 12 & 10 & 10 \\
\hline
\end{tabular}

$\sigma_{x}, \sigma_{y}$ は標準偏差 (変動幅) であり， $\sigma_{x y}$ は共分散で， $\sigma_{x y} \leq \sigma_{x}+\sigma_{y}$ が知られており，変動の幅を小さく見積 もることが可能である。さらに $2 つ の$ 施策の変動幅の変化 が独立であるとすれば，共分散が 0 となるため, $\sqrt{\sigma_{x}^{2}+\sigma_{y}^{2}}$ の幅を余裕分として考えてもよい。

\section{4. 提案手法の適用評価}

〈4.1〉利用デー夕本章では架空の制約条件データを 作成し，提案手法に適用することで，適用評価を行う。こ こでは，表 3 および表 4 に示すデータを利用する。なお， このデータは簡単のため, 実際規模の問題に対して単純化 している。これは実際の IT 投資戦略立案時に利用したデー タでは施策数が多く (68 施策)，限られた紙面で表現する のは困難であるためである。

また , 表 3 , 表 4 以外にも下記のような施策間制約が存 在する。

(1) 実行可能時期

施策 $\mathrm{B}$ は 2 年目まで, 施策 $\mathrm{F}$ は 1 年目まででない と実施できない。

(2) 実行必要性

施策 $\mathrm{A}$ と施策 $\mathrm{F}$ は必ず実施する。

(3) 導入順序

施策 $\mathrm{C}$ の前に施策 $\mathrm{B}$, 施策 $\mathrm{F}$ の前に施策 J , および 施策 M の前に施策 L を実施する必要がある。

(4) 排他的施策

施策 I と施策 J はどちらか一方のみ実施できる。

(5) 相乗効果

(施策 $\mathrm{C}$, 施策 $\mathrm{F})$, (施策 $\mathrm{J}$, 施策 $\mathrm{M}$ ) (施策 $\mathrm{L}$, 施 策 O) の各組合せを同時に実行すると +5 の効果が ある。(施策 $\mathrm{G}$, 施策 $\mathrm{H}$ ) の組合せを実行すると - 5 の効果となる。

〈4.2〉 適用結果 4.1 節のデータを提案手法に適用し た結果を図 5 に示す。また，相乗効果を考慮せずに構筑し たロードマップを図 6 に示す。図 5,6 は共に横軸か時間， 縦軸が人員を表している。図 6 はロードマップの初期案で あり，施策 $\mathrm{G}$ を導入対象から外し，代わりに施策 $\mathrm{O}$ を導 入することで図 5 のロードマップが出力されている。

図 5 より，導入順序など樣々な制約条件を考慮した矛盾 のないロードマップを構築することが可能となる。また， 相乗効果を考慮しない图 6 の場合では, 施策 $\mathrm{G}$ と施策 $\mathrm{H}$ を両方導入するが，相乗効果がマイナスに設定されており， 意味のある導入とは言い難い。例えば, 施策 $\mathrm{G}$ がセキュリ ティソフト導入, 施策 $\mathrm{H}$ がファイアオールの強化と類似施 策が挙がっている状況が考えられる。これに対し，相乗効 


\section{表 4 利用データ (施策制約)}

Table 4. Use data (for each measure).

\begin{tabular}{|l|l|l|l|l|}
\hline Measure & $\begin{array}{l}\text { Business } \\
\text { challenge } \\
\text { level }\end{array}$ & $\begin{array}{l}\text { Introduction } \\
\text { period } \\
\text { (month) }\end{array}$ & $\begin{array}{l}\text { Introduction } \\
\text { budget } \\
(\mathrm{M} ¥)\end{array}$ & $\begin{array}{l}\text { Introduction } \\
\text { staff } \\
(\mathrm{man})\end{array}$ \\
\hline A & 10 & 10 & 20 & 4 \\
\hline B & 12 & 8 & 20 & 8 \\
\hline C & 8 & 6 & 40 & 3 \\
\hline D & 6 & 4 & 20 & 4 \\
\hline E & 4 & 12 & 20 & 6 \\
\hline F & 15 & 8 & 30 & 7 \\
\hline G & 10 & 6 & 30 & 4 \\
\hline H & 12.5 & 7 & 50 & 6 \\
\hline I & 7.5 & 8 & 40 & 4 \\
\hline J & 1.5 & 5 & 20 & 2 \\
\hline K & 3.5 & 12 & 10 & 7 \\
\hline L & 4 & 4 & 20 & 4 \\
\hline M & 3 & 8 & 10 & 1 \\
\hline N & 1 & 15 & 10 & 5 \\
\hline O & 0.7 & 10 & 20 & 5 \\
\hline P & 0.3 & 12 & 20 & 2 \\
\hline & & & & \\
\hline
\end{tabular}

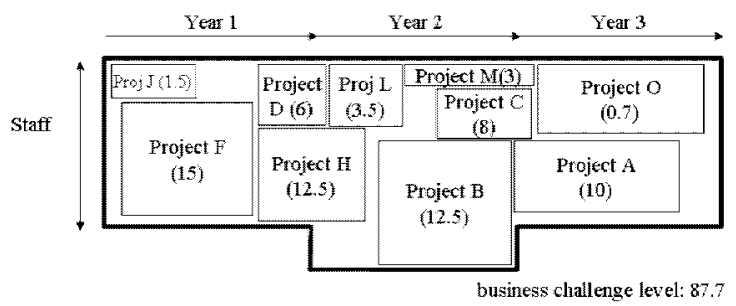

図 5 ロードマップ

Fig. 5. Road map.

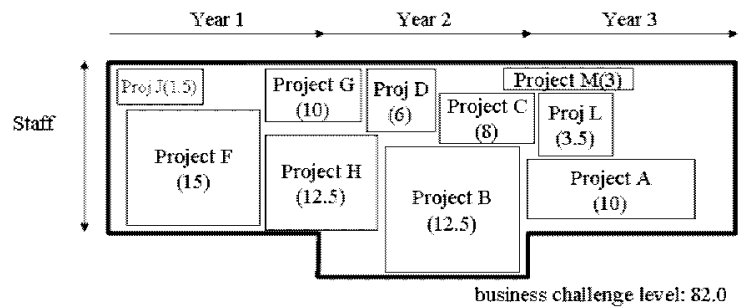

図 6 ロードマップ (相乗効果を考慮せず)

Fig. 6. Road map (Not consider synergy effect).

果を考慮する図 5 の場合は，施策 $\mathrm{G}$ を導入対象とせず，よ り現実に即したロードマップの構築が可能となる。さらに， 相乗効果を考慮することによって，図 6 の累積経営達成度 が 82.0 であるのに対し，图 5 の累積経営達成度が 87.7 と なり，より効果の大きいロードマップを構築することが可 能となる。なお，ここでは架空のデータでの評価を行った が, 実際に利用したデータ (対象 : 68 施策) でも同樣の結 果が得られており，提案手法の妥当性を検証している。ま た，提案手法は実際のロードマップ作成担当者から納得性 の向上の観点から評価されている。

次に，リスクを考慮した場合について考察する。例えば施

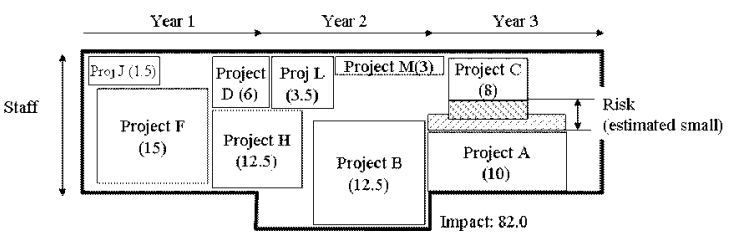

図 7 ロードマップ(リスクを考慮)

Fig. 7. Road map (consider risk).

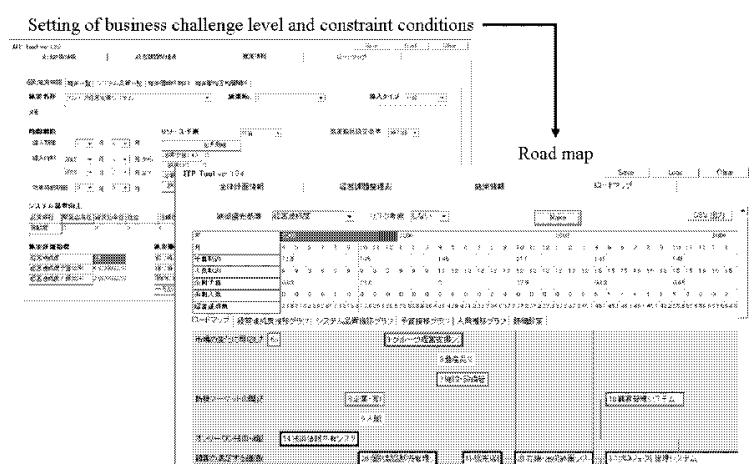

図 8 ロードマップ構築ツール

Fig. 8. Tool of drawing up a road map.

策 $\mathrm{A}$ と C の施策人員のリスクが 2 人ずつであつた場合 , 図 7 に示すように, ロードマップに余裕ができるが，光の分図 5 に対して施策 $\mathrm{O}$ カ抜けるため, 累積経営達成度は低下する。 また，この例ではリスク分散の考え方から， $\sqrt{2^{2}+2^{2}}<3$ と，リスクを小さく見積もられている。特に本適用評価の ように一度に実行可能な施策数が少ない場合は余裕の大き いロードマップが算出される可能性が高い。

\section{5. まとめ}

本研究では,複数施策の投資意思決定を支援するため, 経 営達成度と予算・時間・人員・順序・相乗効果などの制約条 件を考慮した上で，より効果の大きいと予想されるロード マップの構築手法を提案した。また，適用評価を行い，提 案手法の有効性を検証した。なお，图８に示すように提案 手法を実現するツールを実装し，実際の IT 投資戦略立案 に役立てている。

(平成 17 年 8 月 22 日受付，平成 18 年 2 月 7 日再受付)

\section{文献}

（1）清嶋直樹：“IT 投資効果の測定術”，日経情報ストラテジー，Vol.12， No.8, pp.32-45 (2003-8)

（2）譲原雅一・下野谷益・神原 智: IT 投資・IT コストのマネジメン 卜，知的資産創造，野村総合研究所，pp.4-17 (2002)

( 3 ) The Standish Group: "Chaos Report" (1995)

（4）刀根薰・題鍋龍太郎：AHP 事例集，日科議連 (1990)

（5）刀根 薫: PERT 入門，東洋経済新報社 (1977)

(6) ProSight, http://www.prosight.com

(7) A.S. Jain and S. Merran: "Deterministic Job-shop Scheduling: Past, Present and Future", European J. of Operational Res., Vol.113, pp.390-434 (1999) 
中 川忠輔 (正員) 1977 年生。2002 年 3 月大阪大学大学院 工学研究科情報システム工学専攻博士前期課程修 了。同年 (株) 日立製作所に入社。現在 , 同社シ ステム開発研究所において, リスク管理などの研 究に従事。

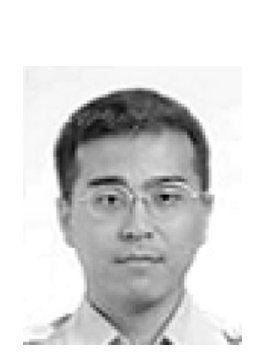

(正員) 1971 年生。96 年東京工業大学総合理工学 研究科修士課程修了。同年 (株) 日立製作所入社。 同社システム開発研究所にて化学プロセス制御技 術および事業リスク管理技法の研究開発に従事。
赤 津 雅 晴 (正員) 1964 年生。 87 年 3 月東京大学工学部計 数工学科卒業。工博。同年 (株) 日立製作所に入 社。システム開発研究所にて, 情報システムの評 価・管理の研究開発に従事。

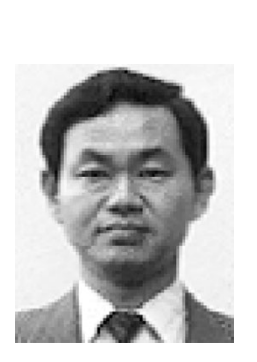

(正員) 1950 年生。1974 年 3 月大阪大学大学院 工学研究科電気工学専攻修士課程修了。同年 (株) 日立製作所入社。1991 年 4 月, 大阪大学工学部情 報システム工学科助教授。2002 年 4 月より, 同大 学大学院情報科学研究科マルチメディア工学専攻 教授。工博。情報システムの計画, 評価等の研究 に従事。電気学会 2000 年度進歩賞等受賞。IEEE 等会員。 